\title{
The Vendian as the Terminal System of the Precambrian
}

\author{
by Boris S. Sokolov and Mikhail A. Fedonkin
}

The Vendian has been recognized for some time in the U.S.S.R. as the oldest stratigraphic division of the sedimentary cover to the crystalline basement and Proterozoic aulocogenes of the Russian Platform. The authors summarize here recent studies on the Vendian of the U.S.S.R. as a preview to a major discussion to be held during the Moscow Congress of this potential new system in the standard stratigraphic column.

\section{Background}

The Vendian was recognized early in the 1950's on the Russian Platform as the oldest stratigraphic subdivision of the sedimentary cover. Extensive work since then has shown that for the first time since 1879, when Lapworth proposed the term Ordovician for the second system of the Palaeozoic, there is now a need to distinguish a major new time division in the evolution of the biosphere and the planet as a whole the Vendian Period.*

The program of deep drilling in the 1940 s played a very important role in studies of the Russian Platform. Information from these boreholes and from exposures of the oldest sedimentary units in the Baltic and the Dniester regions allowed us in 1950 to separate the Vendian from the Cambrian, to correlate the Vendian with the Upper Sparagmite of Scandinavia and with the Sinian of China, and to prepare lithologic and palaeogeographic maps of the Valdai and Baltic series for the Russian Platform. The main features recognized for the Vendian indicated a close link with the Cambrian (which is why it was then called the "Precambrian Palaeozoic") and a structural position at the base of the sedimentary cover overlies either crystalline basement or older Proterozoic deposits confined to narrow tectonic zones - aulacogenes (Sokolov, 1952, 1958).

Since then much progress has been made in the development of the Vendian concept (Sokolov, 1964, 1972, 1973, 1976, 1980; Keller, 1968; Keller et al., 1974; Khomentovskiy, 1976; Rozanov and Sokolov, 1982). During this time a long term program was carried out by the Polish-Soviet working group within the "Precambrian-Cambrian boundary" project, and accounts of the palaeontology, stratigraphy, lithology and palaeogeography of the Upper Precambrian and Cambrian deposits of the western part of the East-European Platform have been published (Volkova et al., 1979; Aren et al., 1979; Fedonkin et al., 1983). Recently the Laboratory of Precambrian Palaeontology of the Academy of Sciences completed another extensive work entitled "The Vendian System: Historical-Geological Substantiation," to be published during the for thcoming Congress in connection with Symposium S.01.2.2

* Editor's Note: There have also been recent calls for a new period and system - the Ediacaran (or Ediacarian) - older than the conventional Cambrian and broadly similar to the Vendian (see P. Cloud and M.F. Glaessner, in Science, August 27, 1982, p. 783-792). (see Coming Events, this issue of Episodes). This account of the new stratigraphic system will embrace worldwide material, including primary basic data from the U.S.S.R.

Outside the U.S.S.R., important work on the Vendian and similar stratigraphic units is being carried out in Australia (Ediacaran), in China (the "Sinian System" sensu stricto) and in a few other countries. The recognition of the Vendian is now arousing worldwide interest in geologists, tectonists, stratigraphers, palaeontologists, specialists on biochemistry and the biosphere, and naturalists in general. In this paper however, we do not attempt to compare or contrast the Vendian with the Ediacaran or Sinian, but concentrate on the data from the U.S.S.R.

\section{General Stratigraphic Aspects}

The Vendian System in the territory of the U.S.S.R. can be illustrated by two types of sections: a terrigenous type on the Russian Platform (from Western Podolia in the south to the White Sea in the north), and a carbonate type on the eastern Olenek Uplift of the Siberian Platform. The first (Fig. 1) is characterized by tillites and basalt sheets in the lower part of the section. The second is characterized by a transgressive overlapping of older Precambrian deposits. The richest localities of soft-bodied Metazoa, their trace fossils, remains of macroflora, various microphytoplankton and other groups of organisms are confined to the Middle Vendian in both regions. Remains of vendotaenid flora, trace fossils of benthic Metazoa, and microfossils are abundant in the Upper Vendian. The Vendian sections in both regions are terminated by characteristic associations of Sabelliditida, Anabarites, numerous diverse trace fossils, and rare remains of medusoids. The base of the Lower Cambrian (Tommotian stage) is characterized by abundant small skeletal organisms that comprise a completely new biota.

\section{The Vendian on the Russian Platform}

The Russian Platform, and in particular its southwestern part, is a stratotype locality for the Vendian, which here includes three series (Fig. 1). The Vilchan series (lowermost) is mainly composed of tillites (Laplandian horizon) deposited following a major glaciation about $700 \mathrm{Ma}$ ago. Traces of this glaciation are, of course, well known on other continents, and tillites provide a good means of stratigraphic correlation (Chumakov, 1978). The Volhyn series is composed of volcanogenic and sedimentary deposits, which may have been deposited rapidly. The Volhyn-Vilchan deposits are confined to aulacogenes, filling the extensive Orshan depression and laterally distributed in Byelorussia and adjacent regions of Poland.

The Valday series, which is sometimes called the Upper Vendian or the Vendian sensu stricto, is more widely distributed and has a similar character throughout the platform (Aren et al., 1979; Bessonova et al., 1980). Two distinct horizons can be distinguished within the Valday series. The older of these, the Redkino horizon, is widely distributed 


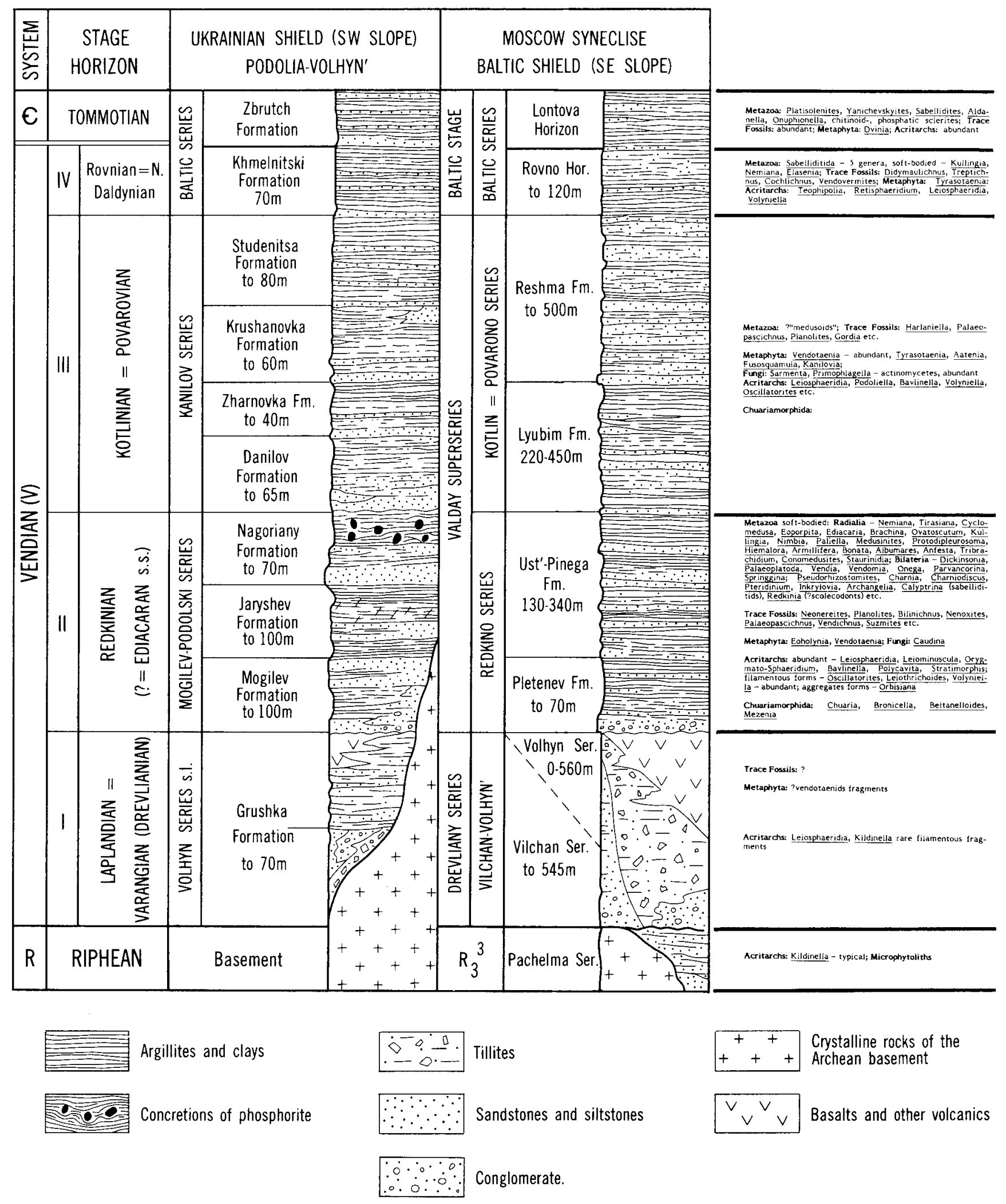

Figure 1: General stratigraphy and palaeontology of the Vendian in the Russian Platform. Roman numerals indicate major faunal divisions. Right-hand column lists the characteristic fossils. 
within the Platform and is represented by sand and clay deposits containing several ash tuff and tuffite members that allow correlation of the Redkino beds over large areas from the Dniester region of Podolia in the west to the Perin region over $2000 \mathrm{~km}$ to the east. These tuffs and tuffites are also distinct in the northern part of the Platform. In contrast to the Vilchan-Volhyn beds, the Redkino horizon and the Valday series as a whole extend beyond the limits of aulacogenes to fill syneclises, which outline the epicontinental basin.

The overlying Kotlin horizon has a similar distribution to rocks of the the Redkino level. Composed of argillites, siltstones, and a minor number of sandstones, the Kotlin horizon lies with an erosive base on the Redkino beds and sometimes rests on even older deposits.

The Vendian of the Russian Platform is terminated by terrigenous beds of the Rovno horizon, which are characterized by a specific assemblage of acritarchs, remains of numerous Sabelliditidae, rare Platysolenites, Aldanella and also by numerous trace fossils of Palaeozoic type (such as Phycodes, Treptichnus, and Gyrolithes) left by benthic invertebrates (Fedonkin et al., 1983). The stratigraphic position and paleontology of the Rovno horizon allow us to compare and correlate it with the Nemakit-Daidyn horizon of Siberia, which is also considered as terminating the Vendian.

It is clear now that the Vendian as a whole is a postaulacogene formation of the Russian Platform. Although the Vilchan-Volhyn deposits are confined to aulacogenes, the pretillite break seems abrupt eve. where, whereas the preRedkino break is a transgressive disconformity.

\section{The Vendian on the Siberian Platform}

The stratigraphic equivalent of the Vendian in Siberia is the Yudomian, composed mainly of carbonates which unconformably overlap the underlying beds. Finds of soft-bodied Metazoa in the Upper Precambrian of Siberia show this to be a region where the Vendian system is widely distributed. The richest known locality for Vendian fauna was discovered in 1981 by us in the Khatyspyt Formation on the Olenek and Khorbusuonka rivers of northern Siberia. In the middle reaches of the Khorbusuonka River the Yudomian deposits can be divided into three formations (Fig. 2): the Maastakh (oldest), Khatyspyt, and Turkut (youngest), which succeed each other within the Khorbusuonka series (Komar, 1966; Shpunt et al., 1979).

The $52 \mathrm{~m}$-thick Maastakh Formation lies with an erosive contact on Riphean dolomites and is composed of variegated volcanogenic rocks with laminae and cross-laminae, and containing beds of fine conglomerates. The upper $25 \mathrm{~m}$ is composed of yellow-grey thin-bedded dolomites.

The basal $12 \mathrm{~m}$ of the $120 \mathrm{~m}$-thick Khatyspyt Formation consists of sandstones and siltstones, but the major part of the unit is composed of limestones and light brown to black bituminous dolomites. Massive beds alternate with thin ones; these are sheared and contain many imprints of Metazoa. Trachybasalt tuff-breccias and tuffaceous siltstones occur in the upper part of the formation.

The Turkut Formation lies disconformably on bituminous carbonates and siltstones of the Khatyspyt Formation. It consists of alternating dolomite members, some containing stromatolites and lenses of microphytolites as well as layers of conglomerate, siltstone and tuff. The formation is 170 . $230 \mathrm{~m}$ thick.

The Kessiusa Formation, which overlaps the Turkut dolomites, is composed mainly of clayey sandstones, siltstones with thin shales (in its lower part), and lenses of carbonates. Abundant and diverse trace fossils occur in this formation as do the oldest small shelly fossils (Missarzhevskiy, 1982).

Analogues of the Vendian are known practically on all continents, not only on platforms but also in geosynclinal regions. Everywhere they occupy the same stratigraphic posi- tion - higher than the tillites of the last Precambrian glaciation and lower than Cambrian deposits characterized by mass appearance of diverse skeletal fauna. Radioisotopic data show that the duration of the Vendian is similar to that of Phanerozoic periods and is not more than $100 \mathrm{Ma}$; the lower boundary has been dated at 650-680 Ma and the upper at 550-570 Ma (Keller and Krasnobayev, 1983). Although more work is needed, it is clear now that in the hierarchy of subdivisions of geological time the Vendian and the Cambrian have an equal status. This conclusion is based not only on historic and geological but also on palaeontological data.

\section{Palaeobiological Aspects}

Studies of the Vendian biota have opened a new and very important chapter in the palaeontological record, for these biota differ sharply from all later ones, in particular from those of the Cambrian. The latter are characterized by the abrupt appearance in the palaeontological record of various groups of Metazoa with a mineralized skeleton in the broad sense (for example, spicules, shells and tests) and, of course, the development of classical palaeontology was based mainly on studies of such skeletal remains.

The Vendian fauna as a whole are characterized by the diversity of taxa of high rank, though species diversity was low in the majority of groups. Reliable data on the divergence or origin of major groups are absent, and all phyla and classes of the Vendian fauna appeared abruptly.

At present the following groups of fossils have been established as occurring throughout the Vendian: procaryotes and life products of procaryotes such as stromatolites and microphytolites, acritarchs (microphytoplankton in the broad sense), unicellular and multicellular eucaryotes (fungi, multicellular vendotaenid algae with a non-mineralized thallus, calcareous algae in the uppermost Vendian, soft-bodied Metazoa, and groups of unclear systematic position), the oldest Metazoa with skeletons based on an organic matrix (Sabelliditida with a chitinous segmented tube), and trace fossils of benthic animals.

The first mineral skeletons, mainly tubular forms, appeared at the end of the Vendian. The biological uniqueness of the Vendian is emphasized by the occurrence of non-skeletal metazoans and macrophyte flora. Over the last ten years extensive localities containing the Vendian fauna have been discovered, in particular in the southeastern White Sea region, the Dniester region of the Ukraine and in Yakutia in the Olenek Uplift. The fossils collected in these regions now exceed in number and diversity all remains of Precambrian animals discovered outside the U.S.S.R, and a major collection is housed in the Palaeontological Institute of the Academy of Sciences in Moscow.

Vendian Metazoa (Fig. 3) are characterized by several peculiar features. Unlike all subsequent Phanerozoic fauna, those of the Vendian are represented by animals that do not have mineralized skeletons. The first small, simple forms with a tubular mineral skeleton appear only at the end of the Vendian. Abundant well-preserved imprints of soft-bodied animals indicate that during this period microphagous organisms were dominant among predators and necrophagues. There is every reason to suppose that relatively short food chains existed in the Vendian and, judging by trace fossils, the infauna did not constitute a large part of the benthic communities. Only in rare cases was the sediment subjected to biological processing. These peculiarities promoted the undisturbed preservation of soft-bodied Vendian organisms.

Gigantism is one of the typical features in several important Vendian faunal groups. This phenomenon is especially striking when non-skeletal Vendian animals are compared with small skeletal fossils of the Early Cambrian. Medusoid forms with a diameter of more than half a meter were not rare in the Vendian, and some feather-shaped colonial polyps reached one meter or more in length. It is possible that gigantism of 


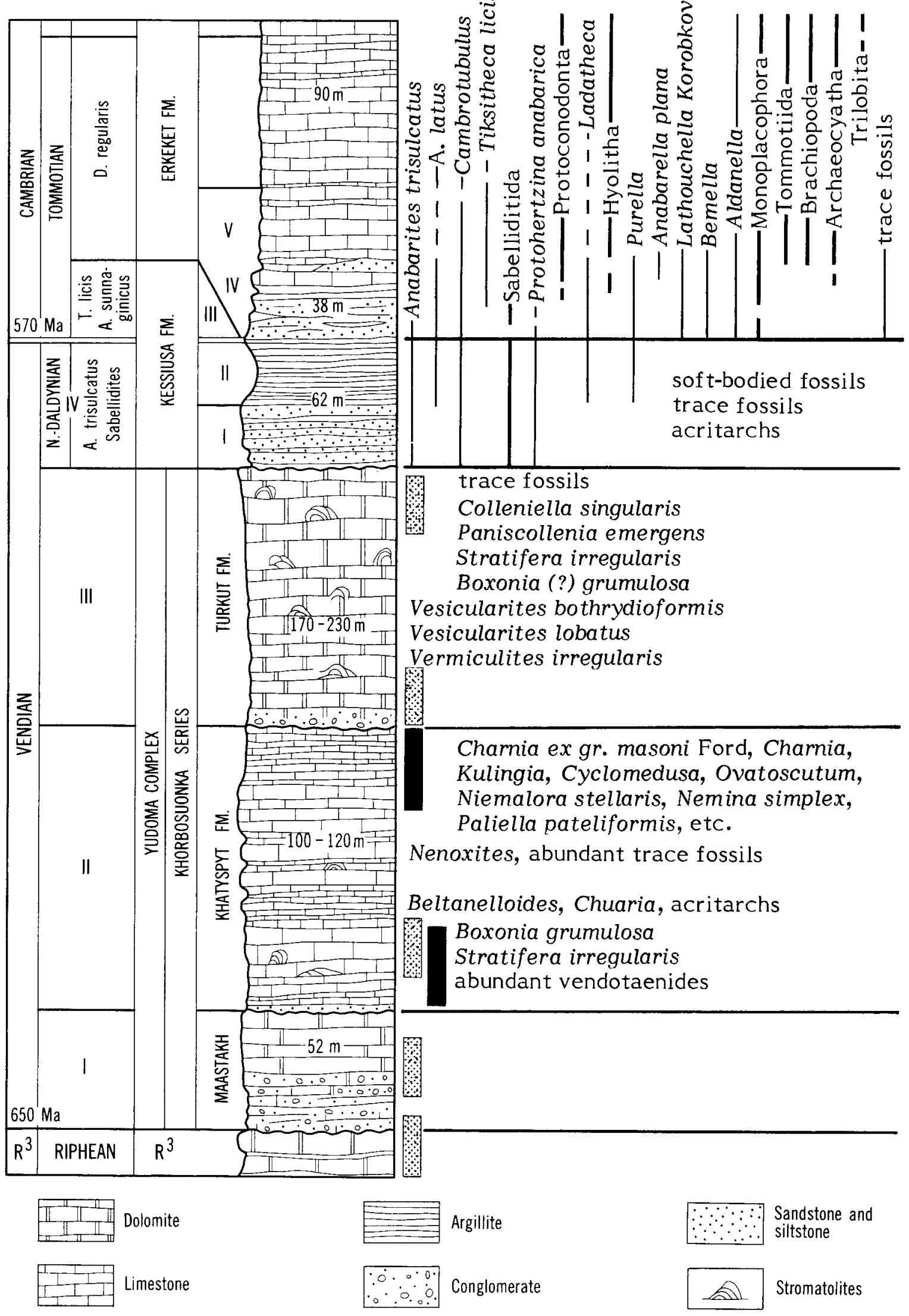

Figure 2: Vendian and Tommotian sequences and palaeontology, Olenek Uplift, Northern Yakutia, Siberian Platform. Stippled bars indicate stromatolites. 

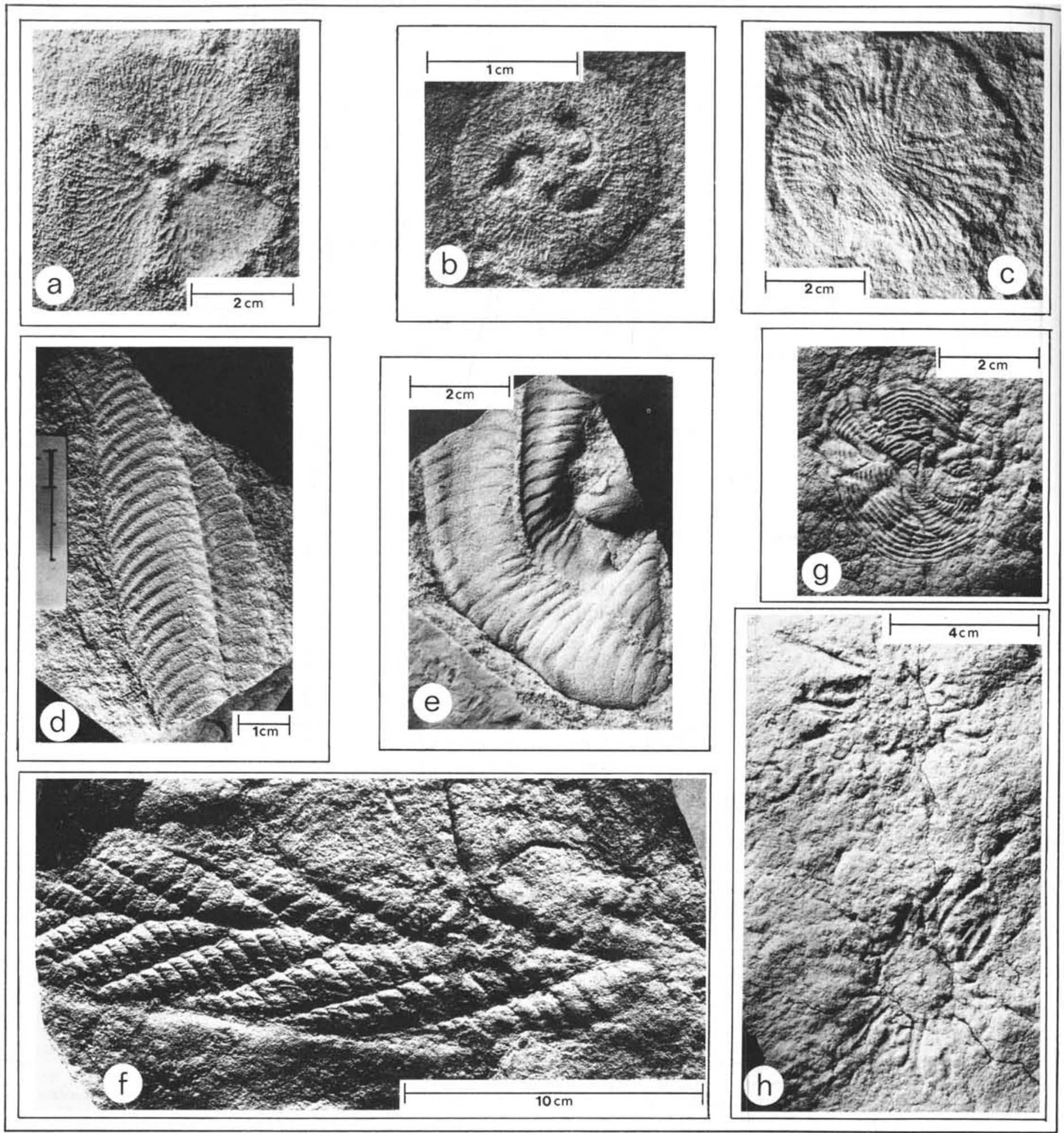

Figure 3: Some typical representatives of the Vendian soft-bodied metazoans from the Ust-Pinega Formation (Redkino horizon, Valdai series), White Sea region: a) Albumares brunsae Fedonkin, b) Tribrachidium heraldicum Glaessner, c) Dickinsonia costata Sprigg, d) Pteridinium nenoxa Keller, e) Inkrylovia lata Fedonkin, f) Charnia masoni Ford, g) Ovatoscutum concentricum Glaessner et wade, $h$ ) Hiemalora stellaris Fe $\overline{d o n k i n}$. 
some Vendian Metazoa is indicative of the phylogenetic termination of their evolution, for such cases are known later in the palaeontological record. In fact, in the majority of cases, we cannot find direct descendants of the Vendian Metazoa among Cambrian organisms. Many typical Vendian forms appear to have been blind alleys in metazoan evolution. However, small non-skeletal or weakly skeletized organisms did exist in the Vendian together with gigantic forms. Some of them, or to be more exact their descendants, promoted the abrupt appearance of skeletal invertebrates at the beginning of the Cambrian.

In the fossil record of Vendian macroscopic metazoans, various Coelenterata were evidently dominant. Medusoids and solitary and colonial polyps constitute $70 \%$ or more of the species in some of the associations (Glaessner, 197la; Fedonkin, 1981: Anderson and Conway, 1982). Though it cannot be ruled out that the preservation potential of Radialia was increased because of the large size of many forms, and because numerous polyps produced imprints while in their life position, the predominance of Coelenterata in the Vendian can be considered as a sign of the great age of this phylum. This conclusion supports models that place Radialia at the base of the metazoan phylogenetic tree.

Diversity of symmetry in the Vendian Coelenterata reflects an initial radiation of the phylum. The most primitive forms have an infinitely high order of symmetry and concentric body plan, such as Nemiana, Beltanelliformis, Tirasiana, Cyclomedusa, and Kullingia. Flat plate-like polyps (or sedentary medusoids) lying on or attached to the bottom were very common. Many of these forms show various methods of asexual reproduction. They passively collected small food particles on their broad oral surface. High population density of such forms as Nemiana and Ediacaria may indicate that this mode of life was very successful in the Vendian. All these plate-shaped or cup-shaped forms with thick mesogloea, concentric body plan, simple gastral cavity and lacking both distinct radial gastro-vascular canals and reproductive organs, can be united in a specific class Cyclozoa (Fedonkin, $1983 \mathrm{a}, \mathrm{b})$, which for the most part became extinct in the upper part of the Vendian:

Precambrian Coelenterata with radial body plan are more advanced, and real medusoids are dominant among these forms. Many different organisms such as Hallidaya, Bonata, Hiemalora and Elasenia increase their degree of radial symmetry during ontogeny. This phenomenon seems to be a very primitive, but necessary, stage in the evolution of many lines of early cnidarians.

Among Radialia with stable symmetry the most common are three-fold (e.g. Skinnera, Albumares and Tribrachidium) and four-fold forms (e.g. Rugoconites, Conomedusites and Persimedusites). Those with three-fold symmetry may represent either a special sub-class of Scyphozoa or a separate class of Coelenterata. This group possibly gave rise to the small conical skeletal forms of the order Angustiochreida (Valkov and Sysoyev, 1969; Valkov, 1982) at the end of the Vendian and the beginning of the Cambrian (Fedonkin, 1983a). Some four-fold Radialia could in parallel have given rise to Conulariida (Glaessner, 1971b). One could suppose that many tubular skeletal forms, which first appear at the Precambrian-Cambrian boundary, represent some groups of primitive Coelenterata.

The vast majority of Vendian bilateral metazoans are characterized by a flattened segmented body. This seems to indicate that the bilateral symmetry and segmented character (metamerism) in many groups of Metazoa could have evolved simultaneously (Fedonkin, 1983a). Among macroscopic Bilateria it is possible to see the phenomenon of imperfect metamery, both in many-segmented forms like Dickinsonia, and in forms like Vendia with few segments.

Most of these species had poor organization and cannot be attributed to any known metazoan taxa of high rank. For example, the flat leaf-shaped segmented form Dickinsonia has been considered as a representative of Coelenterata, Plathelminthes or Annelida. Its ontogeny indicates a possible close historical relationship with Radialia. We suspect that Dickinsonia represents one of the most primitive branches of Bilateria, which possibly did not have any phylogenetic continuation. In this case as in many others, we prefer to speculate about the level of organization rather than about the systematic position of the Vendian metazoans. In some forms it is difficult even to imagine the mode of life (such as feeding and reproduction) and the functional value of some characteristic features. This is true, for example, of the enigmatic Petalonamae.

The Vendian flora are represented by abundant and diverse micro-plankton and non-mineralized strap-like macroscopic algae. The latter belong to the oldest macrophytes and are united in the formal group Vendotaenides (Gnilovskaya, 1971, 1979). Strap-like bifurcating plants up to $150 \mathrm{~mm}$ long and $0.5-3.5 \mathrm{~mm}$ wide, or cord-like bushy forms $10 \mathrm{~mm}$ high, are the most typical ones. Some forms of the genus Vendotaenia have sporangia of two types ranging from 54 to $94 \mathrm{~mm}$ and arranged in longitudinal rows. The form of the thallus and the position of sporangia allow us to suppose that vendotaenids are brown algae.

In addition to the vendotaenids, a group of micro-organisms discovered in the Vendian of the East-European Platform is now definitely assigned to the oldest Actinomycetes (genus Primoflagella). They are simple microscopic, tubular organisms with a wide "head" (sporangium) and long "tail." They form dense clusters, and some occur on the surfaces of vendotaenid thalli and on sapropelic films. They are typical epiphytes.

\section{Biostratigraphic Features}

Unlike the remains of multicellular animals which are most numerous in the Redkino horizon, the distribution of the Vendian macroflora shows a certain regularity that allows us to use them for biostratigraphy (Fig. 4). In the type-section of the Vendian, the Lower Vendian (Redkino) is characterized by the genus Eoholynia, whereas in the Upper Vendian the forms of the genus of Vendotaenia are widespread, and Aataenia are rare. In the uppermost vendian the vendotaenid flora are replaced by the Tyasotaenia flora, which occur in the Rovno horizon terminating the Vendian section on the Russian Platform.

For division and correlation of the Vendian deposits, Soviet specialists in recent years have used acritarchs (Volkova et al., 1979). These are mainly the remains of microscopic organic walled algae, but they also include representatives of other groups of procaryotic and eucaryotic organisms. The ease of their extraction as well as their diversity gives every reason to consider them as one of the guide fossil groups for stratigraphic study of the Vendian and also the Upper Precambrian in general.

\section{Summary}

The studies of Vendian biota are very important for understanding the development of life in the Late Precambrian, its main features, and the earliest pathways of animal evolution, all of which are difficult to predict theoretically. Indeed, the recent Soviet work on Vendian palaeontology and stratigraphy is of global importance, because it extends by one hundred million years the time range of application of classical palaeozoological methods in biostratigraphy.

These investigations are especially significant, because they reveal a new geochronological stage (Fig. 4), one with nonmetallic and other mineral resources necessary for industry and agriculture such as phosphorites and oil. International cooperation in studies of the Vendian system, taking into account the Soviet experience, will be of decisive importance for new advances in the study of the latest Precambrian and of the evolution of life over the last 700 million years. 


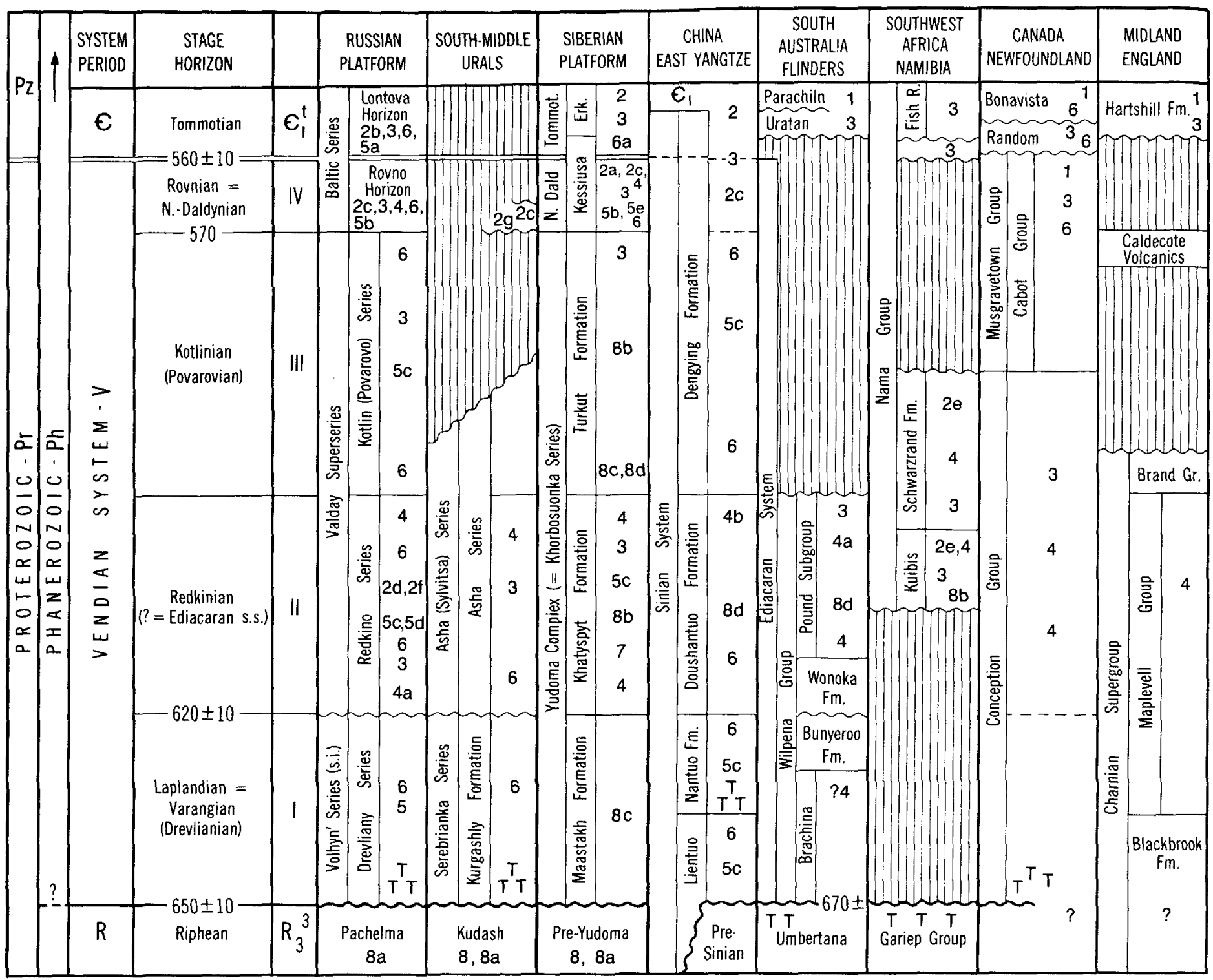

Figure 4: Correlation of the Soviet Vendian with the most important Upper Proterozoic sequences elsewhere. Key to fossils: 1 -skeletal Metazoa, 2 - Tommotian assemblages (2a-Anabarites tris., $2 b$ - Platysolenites, $2 \mathrm{c}$ - Sabelliditida, 2d - Calyptrina, $2 e$ - Cloudina, $2 f$ - Redkinia, $2 g$ - Sabellitidita beds of East Urals slope); 3 trace fossils; 4 -Vendian soft-bodied fossils (4a-Type assemblage: Cyclozoa, Dickinsoniidae, Vendomiidae, Charniidae, Pteridiniidae, Tribrachidium; $4 b$ - Liaoning assemblage); 5 - algae, Vendotaenides ( $5 a-$ Dvinia, $5 b$ - Tyrasotaenia, 5c - Vendotaenia, 5d - Eoholynia, 5e - Korilophyton); 6 - acritarchs (6a - Lontova assemblage); 7 - Chuariamorphida; 8 - stromatolites $(8 a$ - microphytoliths, $8 \mathrm{~b}$ - Yudomian assemblage with (8c) stromatolites and (8d) microphytoliths); $T$ - tillites. 
Academician B.S. Sokolov is Secretary of the Department of Geo$\log y$, Geophysics and Geochemistry of the Academy of Sciences (Leninsky pr. 14, 117901 Moscow V-71). $\mathrm{He}$ is also Chairman of the U.S.S.R. Stratigraphical Committee, President of the All-Union Palaeontological Society and President of the International Palaeontological Association. He was recently elected an Honorary Fellow of the Geological Society of Amer-

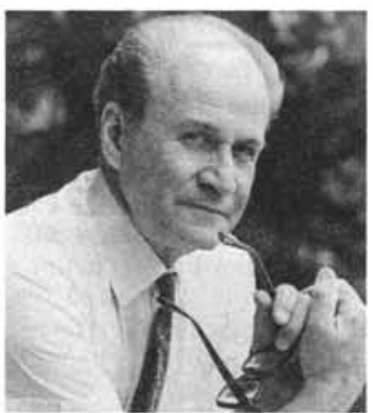

Dr. M.A. Fedonkin is a senior scientist in the Laboratory for Precambrian Palaeontology at the Academy of Sciences (Leninsky pr. 14, 117901 Moscow V-71). His main research interests lie in the fields of Precambrian palaeozoology, palaeoichnology and stratigraphy.

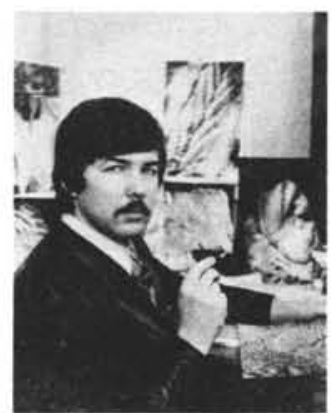

ica.

\section{References (Those not in Russian are asterisked)}

* Anderson, M.M. and Conway Morris S., 1982. A review, with descriptions of four unusual forms, of the soft-bodied fauna of the Conception and St. John's groups (Late Precambrian), Avalon Peninsula, Newfoundland. Third North American Paleontological Convention, Montreal, August 1982, Proceedings, v. 1, p. 1-8.

Aren, B. et al., 1979. Upper Precambrian and Cambrian stratigraphy of the western part of the East-European Platform. Nauka, Moscow, 234p.

Bessonova, V.Ya. et al., 1980. Palaeogeography and lithology of the Vendian and Cambrian of the western part of the EastEuropean Platform. Nauka, Moscow, $119 \mathrm{p}$.

Chumakov, N.M., 1978. Precambrian tillites and tilloides (problems of Precambrian glaciations). Trudy Geologicheskogo instituta, Akademiy nauk SSSR, Nauka, Moscow, v.308, 202p.

Fedonkin, M.A., 1981. White Sea biota of the Vendian. (Precambrian non-skeletal fauna of the Russian Platform north.) Trudy Geologicheskogo Instituta, Akademiy Nauk SSSR, Nauka, Moscow, V.342, 100 p.

*Fedonkin, M.A., 1982. Precambrian softbodied fauna and the earliest radiation of invertebrates. Third North American Paleontological Convention, Montreal, August 1982, Proceedings, v. 1, p. 165-167.

Fedonkin, M.A., 1983a. Organic world of the Vendian. Stratigraphy, Paleontology. Itogi nauki i tekhniki (VINITI), Akademiya nauk SSSR, v. 12, $128 \mathrm{p}$.

*Fedonkin, M.A., 1983b. Promorphology of Vendian Radialia as a key to understanding the early evolution of Coelenterata. Fourth International Symposium on Fossil Cnidaria, August 1983, Washington, D.C. Abstracts, p.6.

Fedonkin, M.A. et al., 1983. Upper Precambrian and Cambrian Palaeontology of the East-European Platform. Wydawnictwa Geologiczne. Warszawa, 158p.

* Glaessner, M.F., 1971 la. Geographic distribution and time range of the Ediacara Precambrian fauna. Geological Society of America Bulletin, v. 82, no.2, p. 509-514.

Glaessner, M.F., 1971b. The genus Conomedusites Glaessner et Wade and the diversification of the Cnidaria. Palaeontologische Zeitschrift, v. 45, no. 1-2, p. 7 17.

Gnilovskaya, M.B., 1971. Oldest Vendian algae of the Russian Platform (Late Precambrian). Paleontologicheskiy Zhurnal, no. 3, p. 101-107.

Gnilovskaya, M.B., 1979. The Vendian Metaphyta. Bulletin des Centres de Recherches exploration-production, Elf-Aquitaie, v. 3 , no. 2, p. $611-618$.

Keller, B.M., 1968. Upper Proterozoic of the Russian Platform (Riphean, Vendian). Essays on regional geology of the USSR, Moscow State University, v.2, 101 p.

Keller, B.M., 1973. Vendian, Yudomian and terminal Riphean (Vendomian). Izvestiya Akademiya nauk SSSR, Seriya geologicheskaya, no. 1, p. 86-92.

Keller, B.M. et al., 1974. Vendomian and its regional subdivisions. Itogi nauki i tekhniki Izd-vo. (VINITI), Moscow, Tom 5, $126 \mathrm{p}$.

*Keller, B.M. and Krasnobayev, A.A., 1983. Late Precambrian geochronology of the European USSR. Geological Magazine, v. 120, no. 4, p. 381-389.

Khomentovskiy, V.V., 1976. Vendian. Trudy Instituta geologiy i geofiziki, Akademiya nauk SSSR, Novosibirsk, v.243, 269p.

Komar, VI.A., 1966. Stromatolites of Upper Precambrian deposits from the north of the Siberian Platform and their stratigraphic importance. Trudy Geologicheskogo instituta, Akademiya nauk SSSR, Moscow, v. $154,122 \mathrm{p}$.

Missarzhevskiy, V.V., 1982. Division and correlation of boundary beds of Precambrian by some oldest groups of skeletal organisms. Byulleten Moskovskogo obshchestva ispytateley prirody, Otdel geologicheskiy, v. 55, no. 4, p. 23-34.

Rozanov, A.Yu. and Sokolov, B.S., 1982. Precambrian-Cambrian boundary: recent state of knowledge. Precambrian Research, v. 17, no.2, p. 125-131.

Shpunt, B.R. et al., 1979. Proterozoic of the northeast border of the Siberian Platform. Nauka, Novosibirsk, $213 \mathrm{p}$.

Sokolov, B.S., 1952. On the age of the old sedimentary cover of the Russian Plat- form. Izvestiya Akademiya nauk SSSR, Seriya geologicheskaya, no. 5, p. 21-31.

Sokolov, B.S., 1958. The problem of the lower boundary of the Paleozoic and the oldest deposits of the pre-Sinian platforms of Eurasia. Trudy Vsesoyuznogo nef tyanogo naucho-issledovatel'skogo geologorazvedochnogo insitituta (VNIGRI), Gostoptekhizdat, Leningrad, v. 126, no. 3, p. 5-67.

Sokolov, B.S., 1964. The Vendian complex (Vendian) and the boundary problem of the Precambrian and Paleozoic Group. In: Geology of the Precambrian. International Geological Congress, XXII Session. Reports of Soviet geologists. Moscow, p. 135-150.

Sokolov, B.S., 1972. The Vendian stage in the Earth history. In: Paleontology. International Geological Congress, XXIV Session. Reports of Soviet geologists, Problem 7. Nauka, Moscow, p. 114-124.

Sokolov, B.S., 1973. Vendian of northern Eurasia. In: Proceedings Second International Symposium on Arctic Geology, San Francisco 1971. American Association of Petroleum Geologists Memoir, no. 19, p. 204-218.

Sokolov, B.S., 1976. Precambrian Metazoa and the Vendian-Cambrian boundary. $\mathrm{Pa}$ leontologicheskiy Zhurnal, no. 1, p. 3-18.

Sokolov, B.S., 1980. Vendian System: the Pre-Cambrian geobiological environment. In: Paleontology, Stratigraphy. International Geological Congress, Paris, 1980. 26 th Doklady Sovetskikh geologov, Nauka, Moscow, p. 9-21.

Valkov, A.K., 1982. Biostratigraphy of the Lower Cambrian of the east Siberian Platform (Uchur-Maya Region). Nauka, Moscow, 92p.

Valkov, A.K. and Sysoyev, V.A., 1969. On new group of animals (angustiochreides) from the oldest beds of the Cambrian of Siberia. XV Session of All-Union Paleont ological Society. Vsesoyuznoye Paleontologicheskoe obshchestvo (VPO), Leningrad, p. 15-16.

Volkova, N.A. et al., 1979. Precambrian and Cambrian Paleontology of the East-European Platform. Nauka, Moscow, 212p. 